\title{
Performance of Textured Metallized Teflon Coverings with High Diffuse Reflectance Coefficient in Low Earth Orbit on ISS
}

\author{
J. I. Kleiman \\ Integrity Testing Laboratory Inc., 80 Esna Park Drive, Units 7-9, Markham, Ontario, L3R 2R7, Canada
}

Received: 23 September 2019 / Accepted: 24 November 2019

\begin{abstract}
A texturing surface modification process was developed for Silver-Inconel coated Teflon thermal protection coverings that were applied to a camera and light equipment on the International Space Station using an adhesive. The developed treatment that involves an ion-beam texturing process that changes the appearance of the surface in a controlled manner from a metallic-like and shiny to complete milky-white appearance reduced dramatically the specularity of Silver-Teflon thermal control films without significantly affecting their thermal optical properties. The space hardware covered with the textured back metallized Teflon was exposed to the open space environment between June 2002 and June 2006 and delivered back to earth around November 2006. Remarkable performance was demonstrated by the treated metallized Teflon with the solar absorptance and total emittance values and the $\alpha / \varepsilon$ ratio remaining very close to the original values as measured before the flights.
\end{abstract}

Keywords: Diffuse reflectance, metallized Teflon, Low Earth Orbit, Innternational Space Station Mobile Servicing System

\subsection{Introduction}

The International Space Station has a large amount of electronic equipment positioned on the outside of the station. Effective thermal control over such equipment is extremely important for normal operation of the station. For extreme thermal environments present in Low Earth Orbit, the standard radiative paints used on electronic boxes for thermal control may have too high absorptivity. The use of metallized Teflon film that has a lower absorptivity is a viable alternative. However, standard back metallized Teflon exhibits excessive glare due to the high specular reflection that can cause problems with cameras installed on the ISS and the Canadaarm. Some of the cameras used on the Mobile Servicing System were designed and manufactured in Canada by MDA. Such cameras are used (among many other tasks) to locate targets attached or in close vicinity to equipment covered with the metallized Teflon films.

Texturing surface modification process was developed for Silver-Teflon film by ITL in order to provide a matt finish $[1,2]$. This product was applied to MDA cameras and lights on the International Space Station using an acrylic adhesive (3M 966). The developed treatment of Silver/ Inconel back metallized Teflon surfaces reduced substantially the specularity of films by changing the morphological appearance of their surfaces by ion-beam texturing in a controlled manner from a metallic-like and shiny to complete milky-white appearance without significantly affecting the thermal optical properties [1].

The camera/light covered with the textured metallized Teflon was launched with the Mobile Base Structure (MBS) on STS-111 in June 2002. The equipment was removed from MBS on June 2006 (which occurred between shuttle missions) and brought inside the ISS. Then it was stored inside the ISS until it was brought down on STS-115 (September 2006) and delivered back to MDA around November 2006. Remarkable performance was demonstrated by the treated Teflon with the solar absorptance and total emittance values and the $\alpha / \varepsilon$ ratio remaining very close to the original values as measured before the flights.

This paper presents some results on the performance of the surface-modified Silver-Teflon thermal control films in the prolonged exposure.

\subsection{Experimental}

All materials used in the present work were prepared from Teflon FEP purchased from Sheldahl (USA). An ionbeam vacuum system containing a linear ion-beam source and a large $58 \mathrm{~cm}$ diameter rotating drum to which the sample was mounted, providing a large surface area of $150 \times 50 \mathrm{~cm}^{2}$ for the ion beam exposure of the samples, was used for 
preparation of the textured material. A typical drum speed of $2 \mathrm{rpm}$ was used in the experiments. High purity krypton gas was used for texturing the films. The chamber vacuum pressure of $3 \cdot 10^{-2} \mathrm{~Pa}$ was maintained during the experiments at the above conditions. Typical etching rates of $0.015 \mu \mathrm{m} / \mathrm{min}$ were achieved in rotational experiments under the described conditions. The details for the experimental set-up can be found elsewhere [1].

The back sides of Teflon samples were coated with a silver/Inconel reflecting coating. The textured surfaces, in accordance with the technical drawing requirements were coated with a $1300 \AA \mathrm{SiOx}$ layer.

Scanning electron microscopy (SEM) study of all samples was performed on a JEOL JSM-T300 model microscope. The surfaces of the polymer samples were coated with a thin layer of carbon to prevent charging.

The solar emissivity (or total emittance) $(\varepsilon)$ of the samples was measured in accordance with the ASTM specification E 408 [3] using an infrared reflectometer manufactured by Gier Dunkle Instruments, Model DB100. The total and the diffuse optical reflectance as well as the solar absorptivity of the samples $(\alpha)$ were measured using a spectrophotometer (Beckman Instruments, Model DK 2a) equipped with an integrating sphere. The solar absorptivity in $\mathrm{UV}$, visible, and the near infrared (IR) ranges of the spectrum, covering the range 200-2450 nm was measured in accordance with the ASTM-E903 specification [4].

\section{Results and Discussions}

\subsection{Texturing Process}

The developed surface texturing process is based on ion-beam bombardment of the surface with noble gases. As a result of such treatment, the specularity of Silver/ Inconel back coated Teflon thermal control films can be reduced dramatically, with the surface morphology changing from metallic-like and shiny to complete milky, white appearance.

Ion beam texturing is a well-known phenomenon [5]. Most ion sputtered fluoropolymer surfaces develop cone or spire-like features. The applications of ion beam textured polymers for adhesion improvement, biomedical applications, electrical properties changes, wettability properties changes, etc., was studied and described [6-8]. It was shown that depending on the ion beam power density and target temperature the etch rates of PTFE range from 3 to $1700 \mu \mathrm{m} / \mathrm{h}$ [8].

An optimization of the process parameters allowed achieving a strong texturing effect. Fig. 1 shows the total and diffuse reflectance of a $127 \mu \mathrm{m}$ thick back metallized Teflon after it was treated with Krypton ions. As can be seen from Fig. 1, most of the light was reflected as diffused, with the diffused reflectance almost equaling the total reflectance.

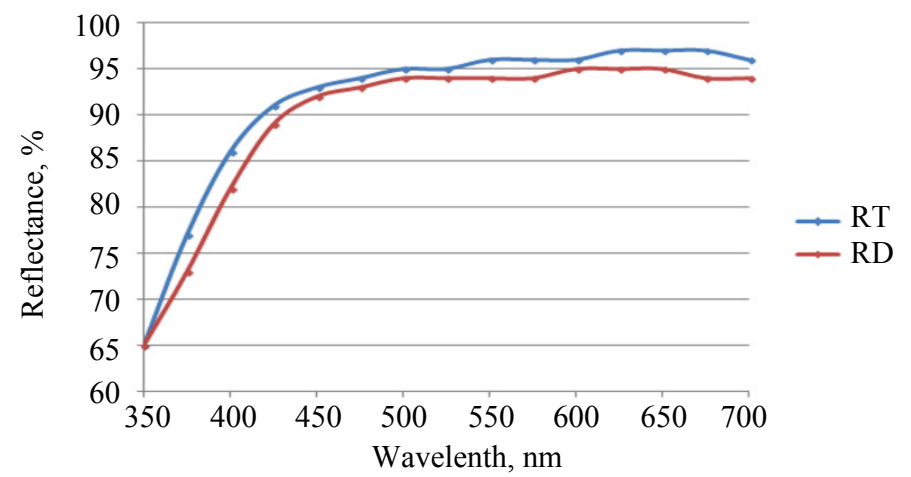

Fig. 1. Total (RT) and diffuse (RD) reflectance measurements for a Ag/ Inconel back metallized Teflon sample after an exposure to a Krypton gas ion-beam

The surface of the treated film attains rough morphology with well-developed cone or spire-like features. Fig. 2 shows planar and cross-sectional SEM images of a sample after a forty hour exposure at optimized conditions.
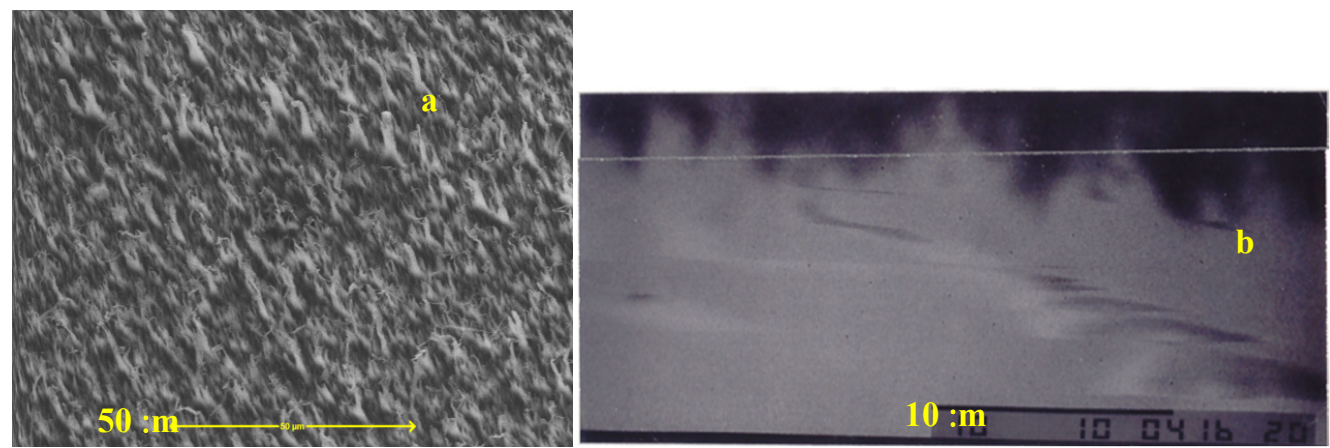

Fig. 2. Planar (a) and cross-sectional (b) scanning electron microscopy images of krypton ion-beam textured Teflon FEP after 40 hours of exposure 

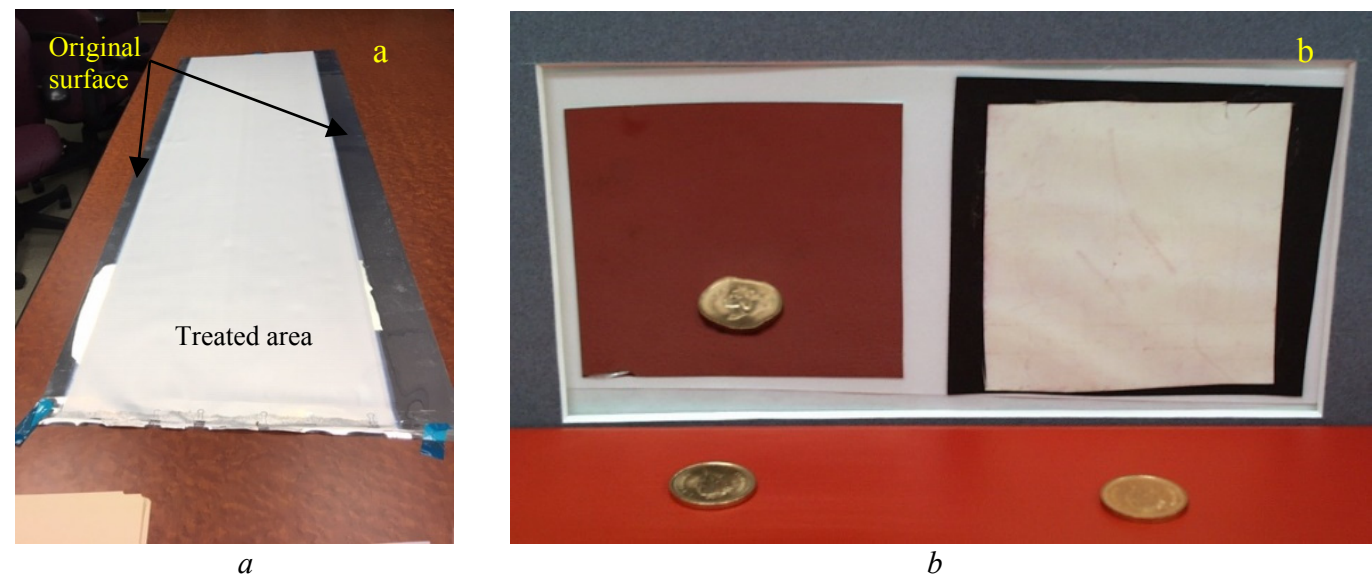

Fig. 3. Optical images of the $\mathrm{Ag}$ / Inconel back-metallized Teflon sheet after treatment $(a)$ and two cut out samples $(b)$ before (left) and after (right) treatment with the texturing process. Coins are placed in front of the samples to demonstrate the total loss of reflectance in the treated sample

As a result of the treatment, the surface of the Ag/ Inconel back metallized Teflon changed from a metallic-like and shiny to complete milky-white (Fig.3) While the surface morphology of the treated sample underwent strong changes, the thermal optical properties of the surfaces practically remained unchanged (table I). As can be seen from table I, all thermal optical parameters underwent very little changes, providing the $\alpha / \varepsilon$ ratio of 0.09 as compared to 0.10 of the original material.

Summary of property changes in the textured Ag/ Inconel back metallized Teflon sample

Table I (not coated with the SiOx coating)

\begin{tabular}{|l|c|c|}
\hline \multicolumn{1}{|c|}{ Parameters } & Teflon Original & Textured Teflon \\
\hline Solar Absorptance $(\alpha)$ & 0.08 & 0.07 \\
\hline Total Emittance $(\varepsilon)$ & 0.79 & 0.81 \\
\hline$\alpha / \varepsilon$ & 0.10 & 0.09 \\
\hline Appearance & Shiny, grey-metallic & Mat, milky-white \\
\hline Total Reflectance $\left(\mathrm{R}_{\mathrm{T}}\right)$ & 0.95 & $0.93-0.95$ \\
\hline Diffuse Reflectance $\left(\mathrm{R}_{\mathrm{D}}\right)$ & 0 & $0.92-0.93$ \\
\hline
\end{tabular}

\subsection{Hardware and Flight Details}

The camera/light unit covered with the textured Ag/ Inconel back metallized Teflon was launched with the Mobile Base Structure (MBS) on STS-111 in June 2002 (Fig.4). The equipment was removed from MBS on June 2006 (which occurred between shuttle missions) and brought inside the ISS. Then it was stored inside the ISS until it was brought down on STS-115 (Sept 2006) and delivered back to MDA around Nov 2006.

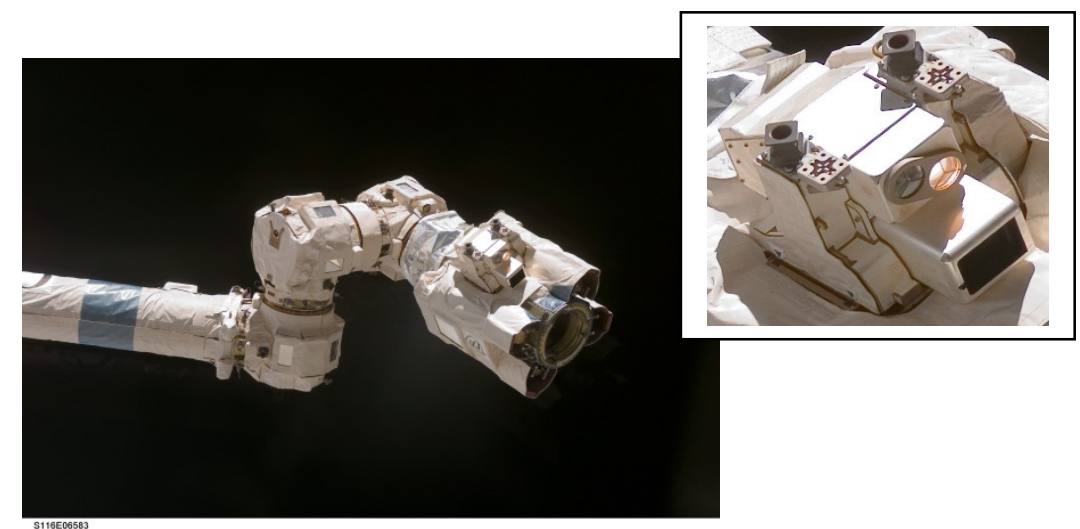

Fig. 4. Image of a portion of the Canadarm 2 with the camera and light on the tip of the Canadarm 2 similar to the used on MBS in STS 111 flight. The insert shows the camera in greater details

The Ag/ Inconel back metallized Teflon surfaces, immediately after return, had the same, complete milky-white appearance (Fig.5). 


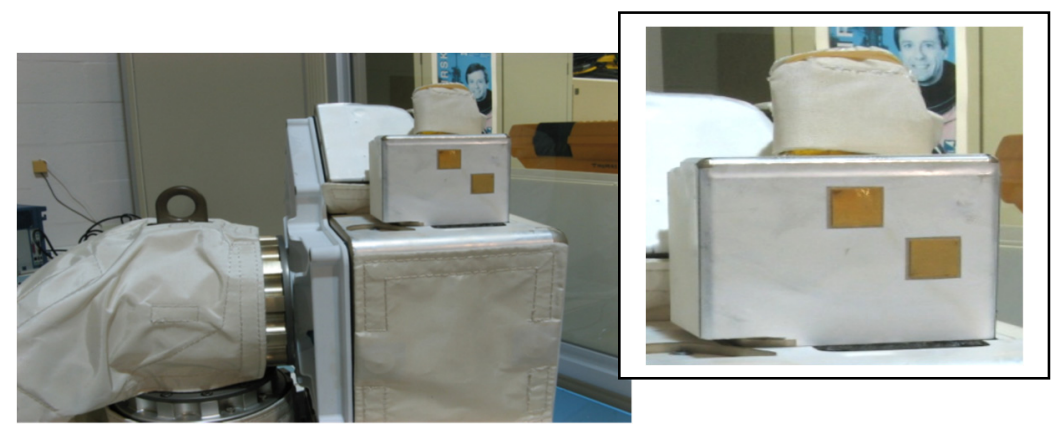

Fig. 5. Visual appearance of the camera CLPA S/N 206 (TVC S/N 209) (stored in a clean room at MDA) after delivery in November of 2006

Figure 6 shows the same camera after 8 months storage in the clean room.

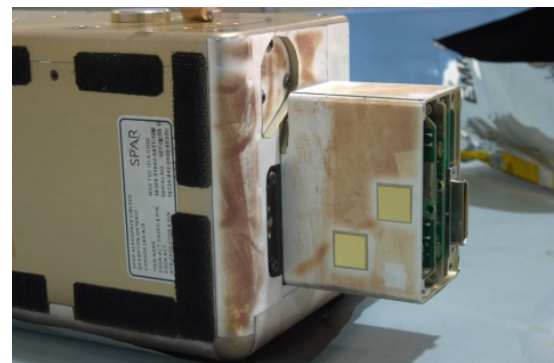

Fig. 6. Visual appearance of the camera CLPA S/N 206 (TVC S/N 209) (stored in a clean room at MDA) after an eight months storage

The thermal optical properties of the textured Teflon surfaces were evaluated after the 8 months of storage. Table II presents the results of the solar absorptance and thermal emittance values as measured in the discolored regions on sides \#2, 3, and 4 and side \#1 that remained relatively milky-white after even the prolonged storage at MDA.

Table II: Thermal optical parameters of the textured Teflon as measured on the camera after return and storage of 8 months. The discolored regions were measured on sides $2-4$ (see Figs 7 and 8 ).

\begin{tabular}{|c|c|c|c|c|}
\hline \multirow{2}{*}{ Side \# } & & \multirow{2}{|c|}{ Table II } \\
\cline { 3 - 5 } & Solar Absorptance, $\alpha$ & Total Emittance, $\varepsilon$ & Flight & \multicolumn{2}{|c|}{$\begin{array}{c}\text { Orig. } \\
\text { (with }\end{array}$} \\
\cline { 3 - 5 } & & & 0.23 & 0.21 \\
\hline 1 & 0.180 & 0.775 & 0.58 & \\
\hline 3 & 0.444 & 0.764 & 0.31 & \\
\hline 4 & 0.248 & 0.803 & 0.39 & \\
\hline
\end{tabular}

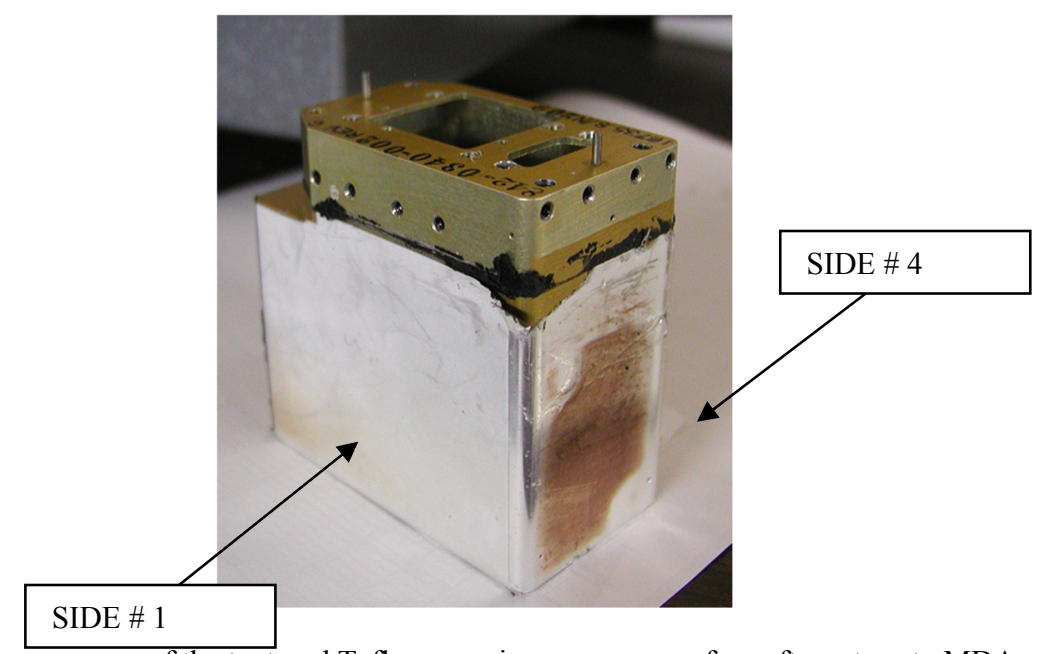

Fig.7. Visual appearance of the textured Teflon covering a camera surface after return to MDA from a space exposure and storage for $\sim 8$ months 


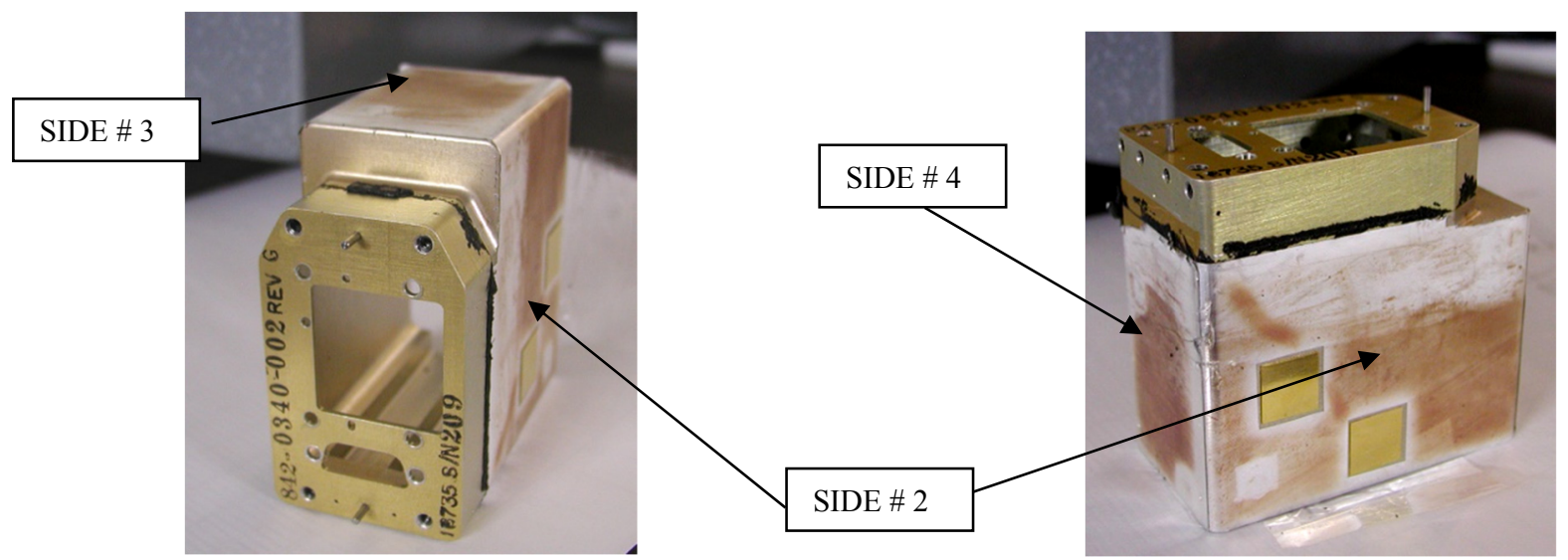

Fig. 8. Visual appearance of the camera (shown in two different positions) covered with the textured Teflon after return to MDA from a space exposure and storage for $\sim 8$ months

A similar phenomenon of Teflon discoloration was observed in one of LDEF experiments that underwent 5.8 years of exposure to the LEO space environment [9]. It was noticed in the Thermal Control Surfaces Experiment (TCSE) samples on LDEF that the front thermal cover consisting of Sheldahl's $50 \mu \mathrm{m}(2$ mil) thick $\mathrm{Ag} / \mathrm{FEP}$ thermal control material glued with Y966 acrylic adhesive that in exposed to the space environment areas the material underwent a clear delineation and attained a diffuse whitish appearance with brown discoloration [9].

Based on the post flight analysis it was established that the brownish streaking was the result of a series of events, starting with the initial cracking of the silver/Inconel layer during application to the TCSE front thermal cover. Subsequent long-term exposure to thermal cycling and solar ultraviolet caused the brownish discoloration. The intensity of the brownish discoloration was found to be a direct function of the crack density that appeared to be caused by excessive handling or stretching [9].

The difference between the case observed in [9] and the one discussed in this paper is that the camera hardware when brought back to MDA did not exhibit the discoloration pattern (Fig. 5) attaining it only after a storage in a clean room (Fig.6).

Table III presents a comparative evaluation of the solar absorptance data for the sample flown on LDEF [9] and the MDA sample after a prolonged storage. As can be seen from table III, the solar absorptance values of the Ag-Inconel coated Teflon are much higher especially in regions with heavier discoloration.

Table III

\section{Comparative evaluation of the solar absorptance data for the samples} flown on LDEF and from MDA

\begin{tabular}{|c|c|c|c|}
\hline & \multirow{2}{*}{ Sample } & \multicolumn{2}{|c|}{ Solar Absorptance, $\alpha$} \\
\hline & & After storage (MDA) or LEO flight (Ref.8) & Original \\
\hline \multirow{4}{*}{ 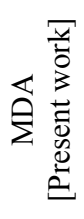 } & 1 & 0.180 & \multirow{4}{*}{$\begin{array}{c}0.09 \\
(0.17 \text { with } \mathrm{SiOx})\end{array}$} \\
\hline & 2 & 0.444 & \\
\hline & 3 & 0.248 & \\
\hline & 4 & 0.316 & \\
\hline \multirow{2}{*}{ 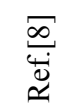 } & Low discoloration & 0.10 & \multirow{2}{*}{0.08} \\
\hline & Strong discoloration & 0.49 & \\
\hline
\end{tabular}

As was mentioned above the Ag/FEP thermal control material used in the LDEF experiment had demonstrated surface erosion by atomic oxygen, attaining diffuse whitish appearance. On the other side, the textured Ag/ Inconel back metallized Teflon material used on the cameras did not show visible signs of change in morphology upon return from orbit. It is plausible to suggest that the layer of SiOx deposited after the texturing helped to prevent the AO erosion of the material in space environment. In addition, XPS analysis of a control and textured by krypton ion beam surface of FEP Teflon indicated that as a result of the texturing, the surface of the treated Teflon becomes fluorine-rich (table IV), thus providing increased additional protection from atomic oxygen erosion. It should be noted that in order to evaluate the resistance of the Teflon FEP surfaces to LEO after texturing the samples were tested in the atomic oxygen beam facility at UTIAS. In all conducted tests, the morphology of the surfaces and the mass of the samples remained practically unchanged. 
Results from a general survey XPS analysis of a control and textured

Table IV by krypton ion beam surface of FEP Teflon

\begin{tabular}{|c|c|c|c|c|}
\hline Sample & $\% \mathrm{~F}$ & $\% \mathrm{C}$ & $\% \mathrm{O}$ & $\begin{array}{c}\mathrm{F} / \mathrm{C} \\
\text { Ratio }\end{array}$ \\
\hline Control & 66.7 & 33.3 & - & 2.0 \\
\hline Kr-sputtered & 69.7 & 30.3 & - & 2.3 \\
\hline
\end{tabular}

\section{Conclusions}

Large areas of Teflon FEP films were successfully textured in a continuous ion beam process using krypton as the ion source. Surfaces with highly developed morphology, having milky mat appearance, were produced, dramatically increasing the diffuse reflectance of the Teflon FEP films without substantially changing their thermal optical properties.

The camera/light units covered with the textured Ag/ Inconel back metallized Teflon were successfully exposed to space on the ISS for a prolonged time while retaining their highly diffuse properties and the required thermal optical properties.

The discoloration effects observed on the textured Teflon after a prolonged storage, upon return of the camera/light equipment, could be associated with oxidation processes occurring in the epoxy used to attach the Ag/Inconel metallized Teflon to the hardware and or the silver layer deposited on the back of the Teflon that could be initiated by the atmospheric oxygen.

As a result of the observed browning effect in storage upon return to Earth and taking into consideration the results reported in [9], MDA has now changed the method by which the Silver-Teflon film is installed. The essential element of this change is to ensure that the film is not bent in too tight a radius so that no micro-cracking occurs in the metal film. All bonded films are also inspected using optical microscopy in order to ensure that no micro-cracks are present.

\section{Acknowledgments}

The authors would like to than Dr. J. Golden for pointing them to the LDEF study paper by J.M. Zwiener, K.A. Herren, D.R. Wilked, L. Hummer and E.R. Miller [9]. The authors also wish to thank Dr. V. Issoupov for help with some thermal optical properties measurements

\section{References}

1. Kleiman J.I., Popov O., Tong A. and Molenda D. "Development of High Diffuse Reflectance Surfaces on Teflon", Proceedings of the Third International Space Conference on Protection of Materials and Structures from the LEO Space Environment, ICPMSE-3, Toronto, 25 - 26 April, 1996, eds. J.I. Kleiman and R.C. Tennyson, Kluwer Academic Publishers. - 1999. - P. 167-178.

2. Kleiman J.I. and Gudimenko Y. "Reduced Glare, High Diffuse Reflectance Teflon Surfaces for Improved Performance of Video Cameras on Canadian MSS for SS Alpha", Proceedings of the 7th International Symposium on "Materials in Space Environment", Toulouse, France, 16 - 20 June, (SP-399, Aug. 1997). - 1997. P. 419-424.

3. Annual Book of ASTM Standards, E408, 15.03.

4. Annual Book of ASTM Standards, E903, 12.02.

5. Banks B. "Topography: Texturing Effects", in "Handbook of Ion beam Processing Technology", Ed. J.J. Cuomo, S.M. Rossnagel, and H.R. Kaufman, Noyes Publications. - 1994. - Vol. 17. 338 p.

6. Mirtich M.J. and Sovey J.S. "Adhesive Bonding of Ion Beam Textured Metals and Fluoropolymers", NASA TM79004, 25th National Vacuum Symposium, San Francisco, CA, Nov. 28 - Dec. 1, - 1978.

7. Kowalski Z.W., "Ion-bombardment Modification of Surface Morphology of Solids - A New Direction in Materials Science”, J. Mat. Sci. Letters - 1988. - vol. 7. 845 p.

8. M. J. Mirtich and J.S. Sovey, "Optical and Electrical Properties of Ion Beam Textured Kapton and Teflon", NASA TM-73778, presented at 24th National Vacuum Symposium, AVS, Boston, MA, Nov. 8-11, 1977.

9. J.M. Zwiener, K.A. Herren, D.R. Wilked, L.Hummer and E.R. Miller, "Unusual Materials Effects Observed on the Thermal Control Surfaces Experiment" (S0069), in Proceedings of Symposium "LDEF-69 Months in Space", Kissimmee, Fla, June 2 - 8, 1991, NASA Conference Publication 3134. - 1991. - Vol. 3. P. 919-934. 


\title{
Поведение текстурированных металлизированных тефлоновых покрытий с высоким коэффициентом диффузного отражения на низкой околоземной орбите на МКС
}

\author{
Я. И. Клейман
}

Аннотация. Процесс модификации поверхности текстурированием был разработан для лицевых поверхностей тефлоновых теплозащитных покрытий напылённых с тыльной стороны металлизированным покрытием Silver-Inconel. Эти теплозащитные покрытия приклеивались на наружные стенки корпусов содержащих фотокамеры и световое оборудование на Международной космической станции. Разработанная технология, включающая прочесс текстурирования поверхностей ионнымм пучком, который менял морфологию поверхности с зеркально-гладкой и блестящей до свето-рассеивающей и молочно-белой, значительно снизила зеркальность терморегулирующих пленок, не оказав существенного влияния на их термооптические свойства. Космическая аппаратура, покрытая таким текстурированным тефлоном, подвергалась воздействию факторам открытого космоса в период с июня 2002 года по июнь 2006 года и была возвращена на Землю примерно в ноябре 2006 года. Текстурированный тефлон, пробывший в космосе 4 года, продемонстрировал стабильные

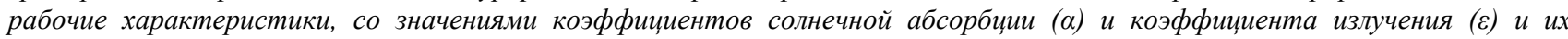
отношения $\alpha / \varepsilon$ сохранившимися близкими к исходным значениям, измеренным до полетов.

Ключевые слова: Диффузная отражательная способность, металлизированный тефлон, низкая околоземная орбита, мобильная система обслуживания международной космической станции

\section{Поведінка текстурованих металізованих тефлонових покриттів з високим коефіціснтом дифузійного віддзеркалення на низькій навколоземній орбіті на МКС}

\begin{abstract}
Анотація. Процес модифікачії поверхні текстуруванням був розроблений для лищьових поверхонь тефлоновим теплозахисних покриттів напиляних з тильного боку металізованим покриттям Silver-Inconel. Ці теплозахисні покриття приклеювалися на наружні стінки корпусів які містять фотокамери та світлове обладнання на Міжнародній космічній станції. Розроблена технологія, щцо включає прочес текстурування поверхонь іонним пучком, який міняв морфологію поверхні з дзеркально-гладенькою до світло-розсіювання і молочно-білою, значно знизила дзеркальність терморегулювальних плівок, не надавши істотного впливу на їх термооптичні властивості. Космічна апаратура, покрита таким текстурированним тефлоном, піддавалася впливу факторів відкритого космосу в період з червня 2002 року по червень 2006 року $і$ була повернута на Землю приблизно в листопаді 2006 року. Текстурований тефлон, що пробув у космосі 4 роки, продемонстрував

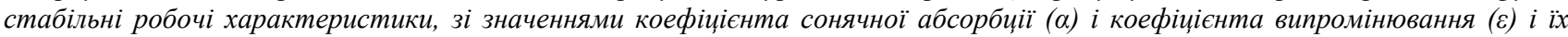
відносин а / в які збереглися близькими до початкових значень, виміряних до польотів.

Ключові слова: Дифузна відбивна здатність, металізований тефлон, низька навколоземну орбіту, мобільна система обслуговування міжнародної космічної станції
\end{abstract}

\section{References}

1. Kleiman, J.I., Popov, O., Tong, A. and Molenda, D. (1999), "Development of High Diffuse Reflectance Surfaces on Teflon", Proceedings of the Third International Space Conference on Protection of Materials and Structures from the LEO Space Environment, ICPMSE-3, Toronto, 25 - 26 April, 1996, eds. J.I. Kleiman and R.C. Tennyson, Kluwer Academic Publishers, pp. 167-178.

2. Kleiman, J.I. and Gudimenko, Y. (1997), "Reduced Glare, High Diffuse Reflectance Teflon Surfaces for Improved Performance of Video Cameras on Canadian MSS for SS Alpha", Proceedings of the 7th International Symposium on "Materials in Space Environment", Toulouse, France, 16-20 June, (SP-399, Aug. 1997), pp. 419-424.

3. Annual Book of ASTM Standards, E408, 15.03.

4. Annual Book of ASTM Standards, E903, 12.02.

5. Banks, B. (1994), "Topography: Texturing Effects", in "Handbook of Ion beam Processing Technology", in J.J. Cuomo, S.M. Rossnagel, and H.R. Kaufman (ed.), Noyes Publications, Ch.17.

6. Mirtich, M.J. and Sovey, J.S. (1978), "Adhesive Bonding of Ion Beam Textured Metals and Fluoropolymers", NASA TM79004, 25th National Vacuum Symposium, San Francisco, CA, Nov. 28 - Dec.1.

7. Kowalski, Z.W. (1988), "Ion-bombardment Modification of Surface Morphology of Solids - A New Direction in Materials Science", J. Mat. Sci. Letters, vol. 7.

8. Mirtich, M.J. and Sovey, J.S. (1977), “Optical and Electrical Properties of Ion Beam Textured Kapton and Teflon”, NASA TM73778, presented at 24th National Vacuum Symposium, AVS, Boston, MA, Nov. 8-11.

9. Zwiener, J.M. Herren, K.A. Wilked, D.R. Hummer L.and Miller, E.R. (1991), "Unusual Materials Effects Observed on the Thermal Control Surfaces Experiment" (S0069), in Proceedings of Symposium "LDEF-69 Months in Space”, Kissimmee, Fla, June 2 - 8, NASA Conference Publication 3134, vol. 3, pp. 919-934, 